\title{
Effect of obesity on molecular characteristics of invasive breast tumors: gene expression analysis in a large cohort of female patients
}

Allyson L. Toro ${ }^{1}$, Nicholas S. Costantino ${ }^{1}$, Craig D. Shriver ${ }^{2}$, Darrell L. Ellsworth ${ }^{1}$ and Rachel E. Ellsworth ${ }^{3 *}$

\begin{abstract}
Background: Obesity is a risk factor for breast cancer in postmenopausal women and is associated with decreased survival and less favorable clinical characteristics such as greater tumor burden, higher grade, and poor prognosis, regardless of menopausal status. Despite the negative impact of obesity on clinical outcome, molecular mechanisms through which excess adiposity influences breast cancer etiology are not well-defined.

Methods: Affymetrix U133 2.0 gene expression data were generated for 405 primary breast tumors using RNA isolated from laser microdissected tissues. Patients were classified as normal-weight (BMI $<25)$, overweight (BMI 25-29.9) or obese (BMI $\geq 30$ ). Statistical analysis was performed by ANOVA using Partek Genomics Suite version 6.6 using a false discovery rate $<0.05$ to define significance.

Results: Obese patients were significantly more likely to be diagnosed $\geq 50$ years or with African American ancestry compared to lean or overweight women. Pathological characteristics including tumor stage, size or grade, lymph node status, intrinsic subtype, and breast cancer mortality did not differ significantly between groups. No significant gene expression differences were detected by BMI in a non-stratified analysis which included all subtypes or within luminal B, HER2-enriched or basal-like subtypes. Within luminal A tumors, however, 44 probes representing 42 genes from pathways such as cell cycle, p53 and mTOR signaling, DNA repair, and transcriptional misregulation were differentially expressed.

Conclusions: Identification of transcriptome differences in luminal A tumors from normal-weight compared to obese women suggests that obesity alters gene expression within ER+ tumor epithelial cells. Alterations of pathways involved in cell cycle control, tumorigenesis and metabolism may promote cellular proliferation and provide a molecular explanation for less favorable outcome of obese women with breast cancer. Targeted treatments, such as mTOR inhibitors, may allow for improved treatment and survival of obese women, especially African American women, who are more likely to be obese and suffer outcome disparities.
\end{abstract}

Keywords: Breast cancer, Obesity, Gene expression

\footnotetext{
* Correspondence: r.ellsworth@wriwindber.org

${ }^{3}$ Clinical Breast Care Project, Murtha Cancer Center, 620 Seventh Street,

Windber, PA 15963, USA

Full list of author information is available at the end of the article
} 


\section{Background}

Data from the Centers for Disease Control and Prevention indicate that $68 \%$ of adults in the United States (US) are overweight $\left(25 \leq \mathrm{BMI}<30 \mathrm{~kg} / \mathrm{m}^{2}\right)$ or obese $(\mathrm{BMI} \geq$ $30 \mathrm{~kg} / \mathrm{m}^{2}$ ) [1]. Obesity is associated with significantly higher all-cause mortality in the general population [2] and has been associated with type 2 diabetes, cardiovascular disease, asthma, osteoarthritis, and many types of cancer [3]. If obesity continues to escalate at current rates, total healthcare costs attributable to obesity-related care could reach $>\$ 860$ billion by 2030 and account for $18 \%$ of total healthcare expenditures in the US [4].

Obesity and weight gain between 20 and 50 years of age are significant risk factors for breast cancer [5] in postmenopausal women $[6,7]$, especially those not using hormone replacement therapy (HRT) [8]. Although the association between body mass index (BMI) and breast cancer subtype is unclear [9-15], obesity has been associated with less favorable pathological characteristics including advanced stage, larger tumor size and metastatic lymph node involvement [16-19]. In addition, metaanalyses have detected significant associations between obesity and both overall and breast-cancer specific survival $[20,21]$.

Given the increasing obesity epidemic in the United States and throughout the world, it is critical to understand how obesity influences breast cancer etiology. Poor prognosis may be attributable to co-morbid conditions, inadequate dosing with chemotherapeutic agents, or biological effects of excess adiposity including increased levels of estrogen, hyperinsulinemia, or chronic inflammation [22, 23]. To better understand relationships between the molecular landscape of tumor epithelial cells and adiposity, gene expression data was generated from 405 microdissected breast carcinomas and analyzed by BMI at the time of diagnosis.

\section{Methods}

\section{Ethics, consent and permissions}

All patients enrolled in the Clinical Breast Care Project met the following eligibility criteria: 1) adult over the age of 18 years, 2) mentally competent and willing to provide informed consent, and 3) presenting to the breast centers with evidence of breast disease. Tissue and blood samples were collected with approval from the Walter Reed National Military Medical Center Human Use Committee and Institutional Review Board. All subjects voluntarily agreed to participate and gave written informed consent.

\section{Specimen collection and characterization}

Tissue was collected from patients undergoing surgical procedures, including lumpectomy or mastectomy. Within 5-15 min of surgical removal, breast tissue was taken on crushed, wet ice to the pathology laboratory where a licensed pathologist or pathologists' assistant performed routine pathological analyses. Diagnosis of every specimen was conducted by a breast pathologist. Stage and grade were assigned using guidelines defined by the AJCC Cancer Staging Manual seventh edition [24] and the Nottingham Histologic Score [25, 26], respectively. Intrinsic subtype was determined using the BreastPRS as previously described [27].

\section{RNA isolation, amplification, aRNA labeling and hybridization}

For each case, the breast pathologist identified tumor areas for laser microdissection from H\&E stained slides. Two to five serial sections ( $8 \mu \mathrm{m}$ thick) were cut, mounted on glass PEN foil slides (Leica Microsystems, Wetzlar, Germany), stained using the LCM staining kit (Applied Biosystems, Foster City, CA) and laser microdissected on an ASLMD laser microdissection system (Leica Microsystems, Wetzlar, Germany). Slide preparation, staining and cutting were performed within a 15 min period to preserve RNA integrity. RNA was then isolated using the RNAqueous-Micro kit (Applied Biosystems, Foster City, $\mathrm{CA}$ ) and treated with DNase I to remove any contaminating genomic DNA. RNA integrity was assessed using the 2100 Bioanalyzer (Agilent Technologies, Santa Clara, CA), converted to biotin-labeled aRNA using two rounds of amplification with the MessageAmpII aRNA Amplification kit (Applied Biosystems, Foster City, CA), and the concentration and quality of the samples was measured with the NanoDrop 1000 (NanoDrop Products, Wilmington, DE) and 2100 Bioanalyzer. Hybridization with manufacturer provided hybridization controls, washing, staining and scanning of HG U133A 2.0 arrays (Affymetrix, Santa Clara, CA) were conducted according to manufacturer's protocols [28].

\section{Analysis and statistics}

For statistical analyses, BMI was not treated as a continuous variable; rather patients were classified as normal-weight (BMI $<25)$, overweight (BMI 25-29.9) or obese (BMI $\geq 30$ ). Analysis of clinicopathological characteristics was performed using chi-square analysis (http://www.physics.csbsju. edu/stats/contingency_NROW_NCOLUMN_form.html) with $P<0.05$ used to define significance.

Gene expression data were analyzed with Partek $^{\odot}$ Genomics Suite v 6.6 (Partek Incorporated). Probe set intensities were obtained by robust multi-array average background correction, quantile normalization, median polish summarization, and $\log _{2}$ transformation. Data integrity was then assessed by standard GeneChip ${ }^{\oplus}$ quality control parameters.

Principal component analysis (PCA) was performed using Partek ${ }^{\oplus}$ Genomics Suite v 6.6 to evaluate whether gene expression patterns effectively separated tumors by 
BMI. The three principal components accounting for the greatest portion of variability in gene expression were used to create a plot in order to visualize possible clustering by BMI groups. Analysis of variance (ANOVA) adjusted for age at diagnosis and self-described ethnicity was used to identify genes differentially expressed between BMI groups with a false discovery rate $(\mathrm{FDR})<0.05$. In the first analysis, all tumor specimens were included followed by subgroup analysis within intrinsic subtype groups (luminal A, luminal B, HER2-enriched, basal-like). Power

Table 1 Clinical and pathological characteristics of 405 primary breast tumors evaluated by microarray analysis

\begin{tabular}{|c|c|c|c|c|}
\hline & Normal-weight $(n=131)$ & Overweight $(n=132)$ & Obese $(n=142)$ & $P$-value \\
\hline Age & & & & 0.031 \\
\hline$<40$ years & 0.15 & 0.11 & 0.06 & \\
\hline $40-49$ years & 0.27 & 0.20 & 0.22 & \\
\hline$\geq 50$ years & 0.58 & 0.69 & 0.72 & \\
\hline Ethnicity & & & & 0.031 \\
\hline African American & 0.17 & 0.19 & 0.32 & \\
\hline Asian & 0.04 & 0.02 & 0.01 & \\
\hline Hispanic & 0.02 & 0.02 & 0.01 & \\
\hline Other & 0.01 & 0.02 & 0.01 & \\
\hline Non-Hispanic White & 0.76 & 0.75 & 0.65 & \\
\hline Tumor Size & & & & 0.130 \\
\hline $\mathrm{T} 1$ & 0.59 & 0.56 & 0.50 & \\
\hline $\mathrm{T} 2$ & 0.35 & 0.34 & 0.45 & \\
\hline T3 & 0.06 & 0.10 & 0.05 & \\
\hline Tumor Grade & & & & 0.216 \\
\hline Well (Grade 1) & 0.23 & 0.21 & 0.19 & \\
\hline Moderate (Grade 2) & 0.42 & 0.35 & 0.32 & \\
\hline Poor (Grade 3) & 0.35 & 0.44 & 0.49 & \\
\hline Intrinsic Subtype & & & & 0.560 \\
\hline Luminal A & 0.52 & 0.48 & 0.54 & \\
\hline Luminal B & 0.13 & 0.08 & 0.11 & \\
\hline HER2-enriched & 0.11 & 0.16 & 0.08 & \\
\hline Basal-like & 0.23 & 0.27 & 0.24 & \\
\hline Normal-like & 0.01 & 0.01 & 0.03 & \\
\hline Lymph Node Status & & & & 0.447 \\
\hline Positive & 0.36 & 0.40 & 0.44 & \\
\hline Negative & 0.64 & 0.60 & 0.56 & \\
\hline TNM Stage & & & & 0.144 \\
\hline Stage I & 0.45 & 0.40 & 0.31 & \\
\hline Stage II & 0.41 & 0.42 & 0.48 & \\
\hline Stage III & 0.12 & 0.12 & 0.18 & \\
\hline Stage IV & 0.02 & 0.06 & 0.03 & \\
\hline Status $^{a}$ & & & & 0.929 \\
\hline Died of disease & 0.08 & 0.07 & 0.07 & \\
\hline Died other causes & 0.02 & 0.03 & 0.02 & \\
\hline Alive with disease & 0.05 & 0.05 & 0.03 & \\
\hline Alive, disease-free & 0.85 & 0.85 & 0.88 & \\
\hline
\end{tabular}

${ }^{a}$ Patient status included died of disease if that patients died of metastatic breast cancer, and died other causes if a patient died from other health conditions. Patients Alive with disease were diagnosed with or have progressed to stage IV breast cancer while those Alive, disease-free have had no additional breast cancer-events since diagnosis and treatment of the original primary breast tumor 
analysis was performed using the MD Anderson Cancer Center sample size calculator (http://bioinformatics. mdanderson.org/MicroarraySampleSize/). Pathway enrichment was performed using the pathway analysis tool in Partek with an enrichment score of $\geq 2.0$ defining significance.

\section{Results}

\section{Patient characteristics}

All patients were diagnosed with invasive breast cancer between 2001 and 2011. Obese women were significantly older at diagnosis $(P=0.009)$ and were significantly more likely to be African American $(P=0.012)$ than normalweight women. Overweight women did not differ significantly for age at diagnosis or ancestry from either normalweight or obese women. No pathological characteristics or patient outcomes differed significantly by BMI (Table 1).
PCA did not effectively cluster samples by BMI (Fig. 1). No differentially expressed genes were detected between BMI groups in the initial analysis which included all tumor subtypes or when comparing obese to non-obese patients. While PCA did not effectively discriminate tumors by BMI, tumors did cluster by intrinsic subtype. Thus, to determine whether the inclusion of a heterogeneous group of tumors was masking significant gene expression differences, analyses were performed within intrinsic subtypes. No differences were detected for luminal B $(n=43)$, HER2-enriched $(n=48)$ or basal-like $(n=99)$ tumors; however, 44 probes from 42 genes were differentially expressed by BMI category (Table 2; Fig. 2) within the luminal A subtype $(n=209)$. These differentially expressed genes are associated with a number of pathways involved in tumorigenesis, such as cell cycle control, mTOR and p53 signaling and DNA repair (Table 3).
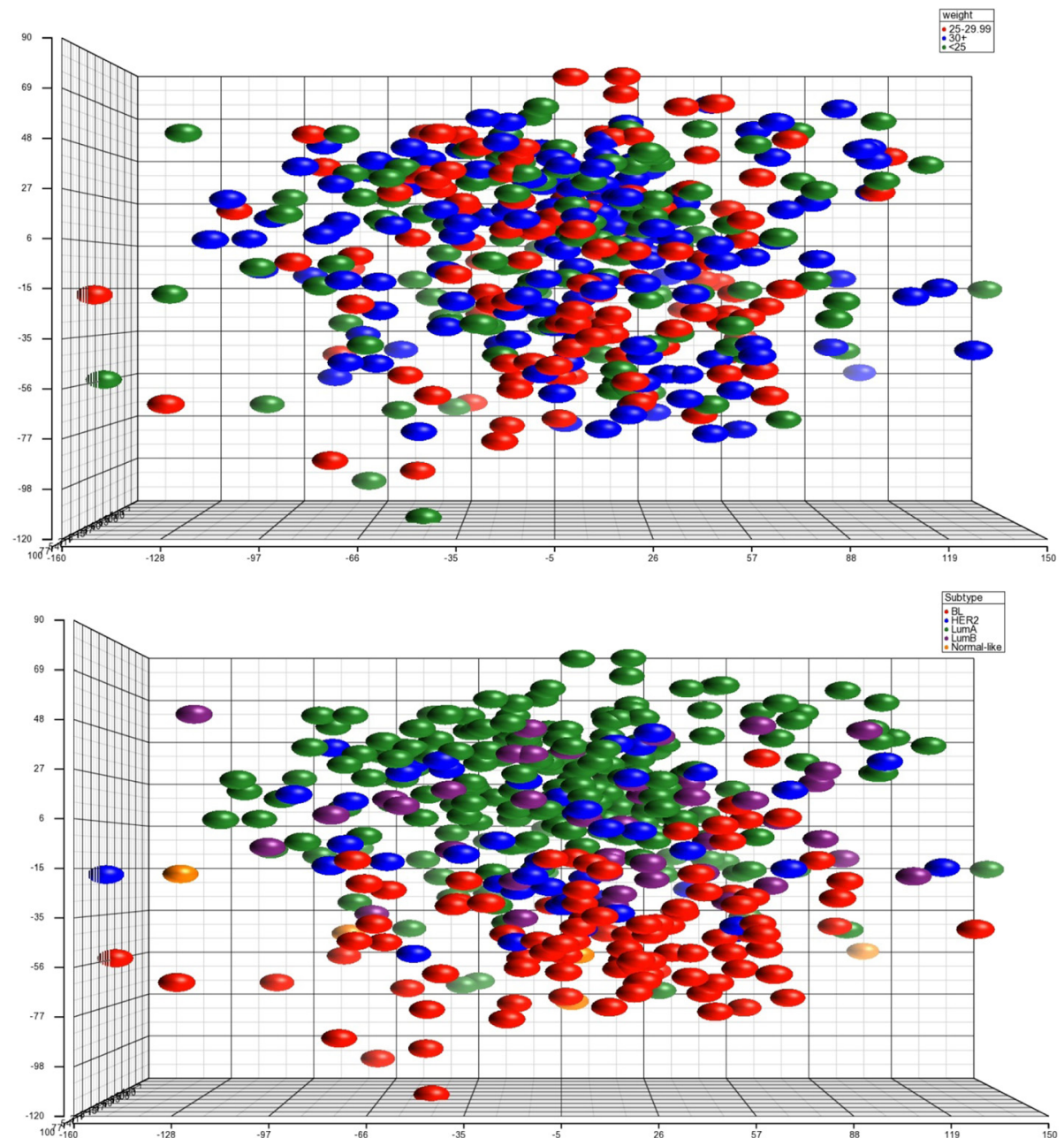

Fig. 1 PCA of gene expression from 405 primary tumor samples. Plot on the top is colored by BMl groups with no obvious clusters detected. Plot on the left is colored by subtype and demonstrates grouping of the samples by subtype 
Table 2 Genes differentially expressed in tumors from normal-weight compared to obese women. Genes in bold remained statistically significant when age at diagnosis and self-described ethnicity were included with BMI in ANOVA

\begin{tabular}{|c|c|c|c|c|}
\hline \multirow[b]{2}{*}{ Gene Symbol } & \multirow[b]{2}{*}{ Probe } & \multirow{2}{*}{$\begin{array}{l}\text { All BMl groups }{ }^{a} \\
P \text {-value }\end{array}$} & \multicolumn{2}{|c|}{ Normal-weight vs obese } \\
\hline & & & $P$-value & Fold-change (normal-weight/obese) \\
\hline $\mathrm{ABCA3}$ & 204343_at & $4.5 \mathrm{E}-05$ & $9.8 \mathrm{E}-06$ & 0.66 \\
\hline ACSL1 & 201963_at & 0.0001 & $3.0 \mathrm{E}-05$ & 1.48 \\
\hline APOD & 201525_at & 0.0002 & $2.3 \mathrm{E}-05$ & 2.36 \\
\hline AVL9 & 212471_at & 4.9E-05 & $9.7 \mathrm{E}-06$ & 0.82 \\
\hline BUB1 & 209642_at & $1.6 \mathrm{E}-05$ & $6.5 \mathrm{E}-05$ & 0.64 \\
\hline CCNB2 & 202705_at & $2.8 \mathrm{E}-05$ & $1.4 \mathrm{E}-05$ & 0.64 \\
\hline CDC25C & 205167_s_at & 0.0002 & 7.4E-05 & 0.67 \\
\hline CDC6 & 203968_s_at & 0.0002 & $8.5 \mathrm{E}-05$ & 0.72 \\
\hline CENPA & 204962_s_at & $8.9 \mathrm{E}-05$ & $3.2 \mathrm{E}-05$ & 0.59 \\
\hline CENPF & 207828_s_at & $2.3 \mathrm{E}-05$ & $6.7 \mathrm{E}-05$ & 0.65 \\
\hline CEP55 & 218542_at & 7.6E-05 & $5.1 \mathrm{E}-05$ & 0.60 \\
\hline CHEK1 & 205394_at & 0.0002 & $5.1 \mathrm{E}-05$ & 0.70 \\
\hline $\mathrm{CORO} 2 \mathrm{~B}$ & 209789_at & 0.0002 & $3.9 \mathrm{E}-05$ & 1.27 \\
\hline DENND1A & 219763_at & $3.3 \mathrm{E}-07$ & $5.0 \mathrm{E}-08$ & 0.66 \\
\hline EXO1 & 204603_at & 0.0003 & $8.8 \mathrm{E}-05$ & 0.80 \\
\hline $\mathrm{EZH} 2$ & 203358_s_at & $3.2 \mathrm{E}-05$ & $1.5 \mathrm{E}-05$ & 0.68 \\
\hline FLRT2 & 204359_at & 0.0005 & $8.6 \mathrm{E}-05$ & 1.60 \\
\hline FOXM1 & 202580_x_at & $1.2 \mathrm{E}-05$ & $8.9 \mathrm{E}-06$ & 0.67 \\
\hline GTSE1 & 204317_at & 0.0003 & 7.7E-05 & 0.83 \\
\hline \multirow[t]{2}{*}{ IGF1 } & 209542_x_at & $2.4 \mathrm{E}-05$ & $6.2 \mathrm{E}-06$ & 1.75 \\
\hline & 211577_s_at & $3.5 \mathrm{E}-05$ & $1.0 \mathrm{E}-06$ & 1.72 \\
\hline KIF14 & 206364_at & $1.5 \mathrm{E}-05$ & $1.0 \mathrm{E}-05$ & 0.70 \\
\hline KIF18B & 222039_at & $9.1 \mathrm{E}-06$ & $1.1 \mathrm{E}-05$ & 0.67 \\
\hline $\mathrm{KIF} 2 \mathrm{C}$ & 209408_at & 0.0002 & $3.0 \mathrm{E}-05$ & 0.66 \\
\hline KIF4A & 218355_at & 0.0001 & $5.5 \mathrm{E}-05$ & 0.64 \\
\hline KLHL12 & 219931_s_at & 0.0005 & $8.4 \mathrm{E}-05$ & 0.79 \\
\hline MELK & 204825_at & 4.0E-06 & $2.2 \mathrm{E}-06$ & 0.58 \\
\hline \multirow[t]{2}{*}{ MKI67 } & 212022_s_at & 0.0007 & $3.5 \mathrm{E}-05$ & 0.69 \\
\hline & 212021_s_at & 0.0002 & $3.4 \mathrm{E}-05$ & 0.71 \\
\hline NUDT13 & 214136_at & 0.0005 & $9.3 \mathrm{E}-05$ & 0.74 \\
\hline OGN & 218730_s_at & 0.0003 & $5.4 \mathrm{E}-05$ & 2.05 \\
\hline OIP5 & 213599_at & 7.5E-05 & $4.5 \mathrm{E}-05$ & 0.67 \\
\hline PARP1 & 208644_at & 0.0004 & $6.7 \mathrm{E}-05$ & 0.81 \\
\hline PDIA4 & 211048_s_at & 0.0005 & $9.5 \mathrm{E}-05$ & 0.80 \\
\hline PRC1 & 218009_s_at & 0.0002 & $7.3 \mathrm{E}-05$ & 0.66 \\
\hline PSMD4 & 200882_s_at & 0.0005 & $9.1 \mathrm{E}-05$ & 0.83 \\
\hline RBMS3 & 206767_at & 0.0003 & $5.9 \mathrm{E}-05$ & 1.28 \\
\hline SCCPDH & 201826_s_at & 0.0005 & $9.8 \mathrm{E}-05$ & 0.73 \\
\hline SERPINB13 & 216258_s_at & $3.9 \mathrm{E}-05$ & 2.6E-05 & 0.93 \\
\hline TADA2A & 209938_at & 0.0005 & $9.1 \mathrm{E}-05$ & 0.84 \\
\hline TIMELESS & 203046_s_at & 1.1. E-05 & $1.5 \mathrm{E}-05$ & 0.75 \\
\hline
\end{tabular}


Table 2 Genes differentially expressed in tumors from normal-weight compared to obese women. Genes in bold remained statistically significant when age at diagnosis and self-described ethnicity were included with BMI in ANOVA (Continued)

\begin{tabular}{|c|c|c|c|c|}
\hline TYMS & 202589_at & $6.5 \mathrm{E}-06$ & $3.9 \mathrm{E}-06$ & 0.65 \\
\hline WHSC1 & 209054_s_at & 0.0003 & 8.6E-05 & 0.81 \\
\hline ZWINT & 204026_s_at & 8.6E-06 & $3.1 \mathrm{E}-06$ & 0.67 \\
\hline
\end{tabular}

${ }^{a}$ Genes that differed significantly in expression levels when ANOVA was performed across normal weight, overweight and obese groups

\section{Discussion}

Worldwide obesity rates are increasing at an alarming rate [29] and in the United States, $>50 \%$ of adults are expected to be obese by 2030 [4]. Given the poor prognosis of obese women with breast cancer, improved understanding of how obesity impacts survival is critical. Identification of molecular profiles in invasive breast carcinomas that correlate with obesity would allow for development of targeted therapeutics or risk reduction strategies that could improve outcomes in obese women. In this study, we detected 42 unique genes that were differentially expressed in luminal A breast tumors from normal-weight compared to obese women. Tumors from overweight patients did not differ significantly from those in normal-weight or obese women.

To our knowledge, this is the first study to identify transcriptomic changes associated with obesity in epithelial cells of luminal A tumors. Kwan et al. evaluated the effects of BMI in a set of 1,676 early-stage tumors where intrinsic subtype was assigned using the PAM50 qRT-PCR assay [11] and found that high obesity (BMI $\geq 35)$ was associated with decreased expression of ESR1 and increased expression of proliferation genes. Of the 10 proliferation genes assayed by Kwan et al., four (CENPF, CEP55, MK167 and KIF2C) were also expressed at significantly higher levels in tumors from obese compared to normalweight patients in our study.

Fuentes-Mattei et al. performed microarray-based transcriptome analysis in ER+ tumors and identified 112 genes differentially expressed between non-obese and obese patients. Gene enrichment analysis detected significant alterations in the AKT-target and epithelial-mesenchymal transition pathways. Activation of the AKT/mTOR pathway was also detected in tumors from obese mice [30]. Although none of the differentially expressed genes from our study were also in the study from Fuentes-

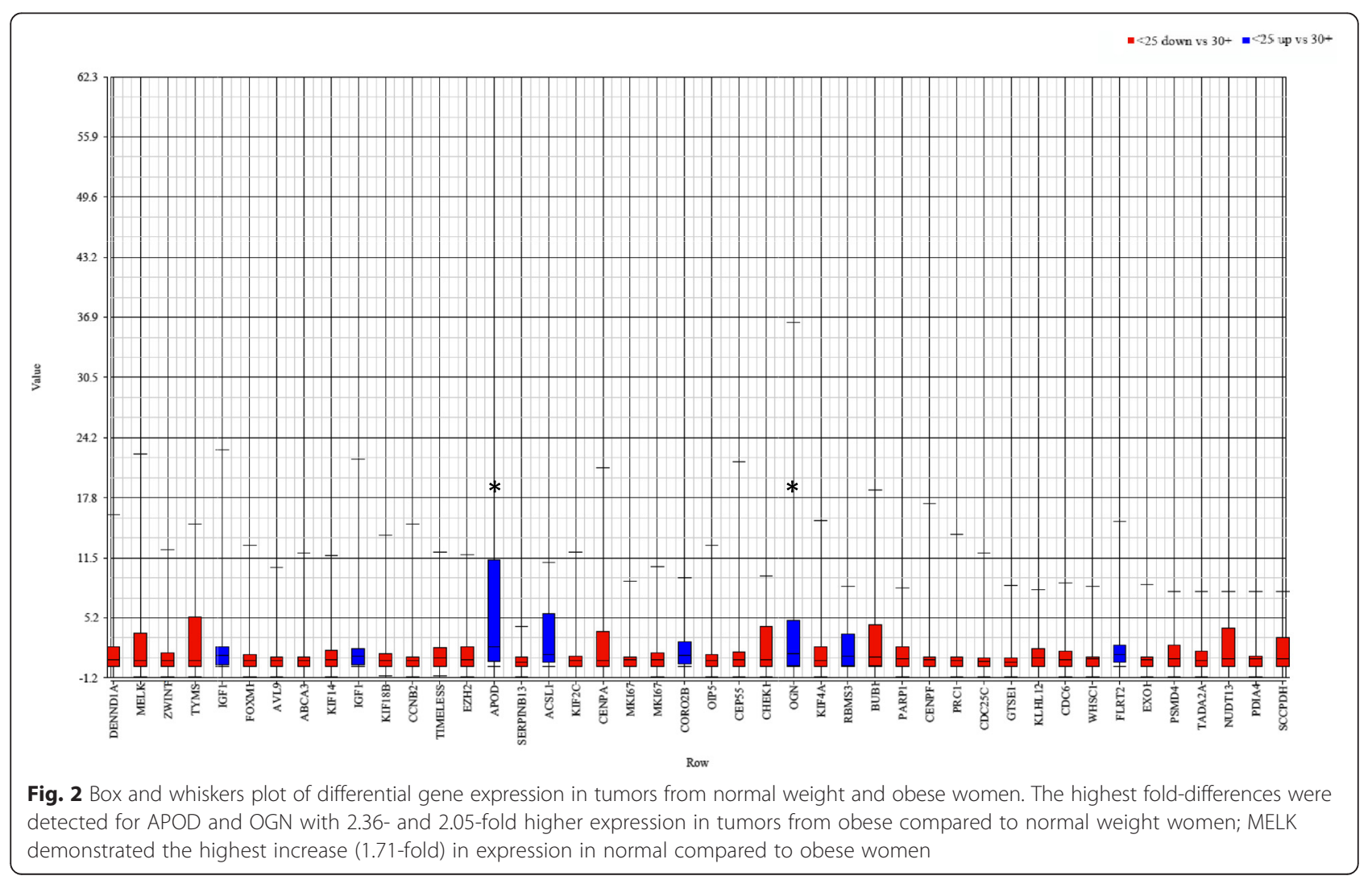


Table 3 Differentially regulated pathways between tumors from normal-weight and obese women

\begin{tabular}{llll}
\hline KEGG pathway & Enrichment score & Enrichment P-value & \% Genes present in pathway \\
\hline Cell cycle & 10.9 & $1.8 \mathrm{E}-005$ & 4.3 \\
p53 signaling pathway & 10.4 & $3.1 \mathrm{E}-005$ & 6.5 \\
Progesterone-mediated oocyte maturation & 9.6 & $7.0 \mathrm{E}-005$ & 5.3 \\
Oocyte meiosis & 8.7 & 0.0002 & 4.2 \\
One carbon pool by folate & 3.1 & 0.0456 & 6.7 \\
Mismatch repair & 2.7 & 0.0692 & 4.3 \\
Base excision repair & 2.4 & 0.0951 & 3.1 \\
Transcriptional misregulation in cancer & 2.3 & 0.0962 & 1.2 \\
ABC transporters & 2.2 & 0.1064 & 2.8 \\
Aldosterone-regulated sodium reabsorption & 2.1 & 0.1175 & 2.5 \\
Fatty acid metabolism & 2.1 & 0.1231 & 2.4 \\
Lysine degradation & 2.1 & 0.1258 & 2.3 \\
Proteasome & 2.1 & 0.1285 & 2.4 \\
mTOR signaling pathway & 2.0 & 0.1394 & 2.1
\end{tabular}

Mattei et al., pathway enrichment analysis of our differentially expressed genes also revealed alterations in the mTOR signaling pathway.

A transcriptomic signature of obesity encompassing 662 differentially expressed genes was previously reported based on tumor biopsy specimens from 103 female patients with locally advanced breast cancer enrolled in neoadjuvant studies, regardless of ER status [31]. Gene annotation enrichment analysis detected an expression signature overrepresented by genes involved in regulation of transcription and nucleus that was associated with shorter time to metastasis in two public data sets; however, no correlation was detected in four other databases. Of note, a significantly higher proportion of African Americans were obese compared to normal or overweight, and a number of differentially expressed probes in their dataset, including 205048_s_at (PSPHL), 206777_s_at (CRYBB2P1) and 212777_at (SOS1), are known to be differentially expressed in a variety of tissue types between African Americans and European Americans [32-39]. Inclusion of late-stage tumors not stratified by subtype or ER status, in combination with confounding gene expression results attributable to genetic ancestry, may have affected the ability to detect transcriptome changes associated with BMI.

A critical difference between our data and other reports is our use of laser microdissection to isolate tumor cells while samples from the other studies were comprised of 15-30 \% stromal cells. Breast adipose tissue serves as fuel for tumor growth, recruits macrophages and stimulates an inflammatory response [40]. Data from our laboratory demonstrated that tumor-adjacent adipose has an altered inflammatory response and increased immunotolerance [41] and recent data demonstrates that co-culturing of ER+ breast cancer cells with adipose stro$\mathrm{mal} / \mathrm{stem}$ cells from obese women enhanced proliferation of the breast cancer cells, and these breast cancer cells demonstrated increased epithelial-mesenchymal transition and expression of metastasis genes [42]. Thus, while laser microdissection of tumor cells may have provided a molecular portrait of gene expression in the tumor epithelia, studies that allowed for a significant proportion of stromal cells, including adipose, may have detected alterations associated with excess adiposity that are present in the tumor microenvironment.

Limitations of this study include lack of long-term follow-up and treatment information as well as limited sample sizes for the non-luminal A subtypes. Samples were collected 2001-2011, thus long-term outcome information was not available for all patients. Given that luminal A tumors have a longer time to relapse (5-15 years) than other subtypes [43], differences in long-term mortality by BMI may not be detected. In conjunction, these patients were treated at WRNMMC, a Department of Defense military hospital. Although all patients within this equal-access health care system are provided standard health care, it was not possible to determine whether treatment regimens were equivalent for obese women, or if any women received agents such as mTOR inhibitors that may be more effective in treating obese women with luminal A breast tumors. Finally, lack of differentially expressed genes in the non-luminal A subtypes, especially luminal B tumors, may reflect small sample sizes. Power analysis demonstrated that to detect $\geq 1.5$ fold expression level differences with $80 \%$ power, a minimum of 43 patients in each BMI group would be needed. Within the luminal A subtype, 68, 64 and 77 tumors were from normal weight, overweight and obese women, respectively; 
across the other subtypes there were a total of 43,48 and 99 luminal B, HER2-enriched and basal-like tumors total.

\section{Conclusion}

Excess adiposity does not affect all breast tumors equally; rather, differential gene expression by BMI was restricted to luminal A tumors. Alterations in pathways associated with cell cycle control, mTOR and p53 signaling, and fatty acid metabolism may explain the less favorable outcomes associated with obesity. In addition, detection of alterations in these pathways allows for the use of agents such as mTOR inhibitors to more effectively treat obese women with luminal A tumors and decrease outcome disparities.

\section{Availability of data and materials}

Microarray data has been deposited in GEO (http:// www.ncbi.nlm.nih.gov/geo/; Accession number: GSE78958).

\section{Abbreviations}

BMI: body mass index; ER: estrogen receptor; HRT: hormone replacement therapy.

\section{Competing interests}

The authors declare that they have no competing interests.

\section{Authors' contributions}

ALT generated the gene expression data for all of the primary tumors and reviewed the manuscript, NSC assisted in statistical analysis and interpretation and reviewed the manuscript, CDS collected patient specimens and provided clinical interpretation of the data, DLE assisted with data interpretation and reviewed the manuscript, REE conceived of project, analyzed the gene expression data and wrote the manuscript. All authors read and approved the final manuscript.

\section{Acknowledgements}

The views expressed in this article are those of the authors and do not reflect the official policy of the Department of Defense or U.S. Government. This research was supported by a grant from the Office of the Congressionally Directed Medical Research Programs (Department of Defense Breast Cancer Research Program W81XWH-11-2-0135).

\section{Author details}

${ }^{1}$ Clinical Breast Care Project, Chan Soon-Shiong Institute of Molecular Medicine at Windber, 620 Seventh Street, Windber, PA 15963, USA. ${ }^{2}$ Clinical Breast Care Project, Murtha Cancer Center, Walter Reed National Military Medical Center and Uniformed Services University, 8901 Wisconsin Avenue, Bethesda, MD 20889, USA. ${ }^{3}$ Clinical Breast Care Project, Murtha Cancer Center, 620 Seventh Street, Windber, PA 15963, USA.

Received: 17 December 2015 Accepted: 20 April 2016

Published online: 29 April 2016

\section{References}

1. Ogden $C L$, Carroll MD, Flegal KM. Prevalence of obesity in the United States. JAMA. 2014;312(2):189-90.

2. Flegal KM, Kit BK, Orpana H, Graubard BI. Association of all-cause mortality with overweight and obesity using standard body mass index categories: a systematic review and meta-analysis. JAMA. 2013;309(1):71-82.

3. Guh DP, Zhang W, Bansback N, Amarsi Z, Birmingham $C L$, Anis AH. The incidence of co-morbidities related to obesity and overweight: a systematic review and meta-analysis. BMC Public Health. 2009:9:88,

4. Wang Y, Beydoun MA, Liang L, Caballero B, Kumanyika SK. Will all Americans become overweight or obese? estimating the progression and cost of the US obesity epidemic. Obesity. 2008;16(10):2323-30.
5. Santen RJ, Boyd NF, Chlebowski RT, Cummings S, Cuzick J, Dowsett M, Easton D, Forbes JF, Key T, Hankinson SE, et al. Critical assessment of new risk factors for breast cancer: considerations for development of an improved risk prediction model. Endocr Relat Cancer. 2007;14(2):169-87.

6. Renehan AG, Tyson M, Egger M, Heller RF, Zwahlen M. Body-mass index and incidence of cancer: a systematic review and meta-analysis of prospective observational studies. Lancet. 2008:371(9612):569-78.

7. Cheraghi Z, Poorolajal J, Hashem T, Esmailnasab N, Doosti Irani A. Effect of body mass index on breast cancer during premenopausal and postmenopausal periods: a meta-analysis. Plos ONE. 2012;7(12):e51446.

8. Morimoto LM, White E, Chen Z, Chlebowski RT, Hays J, Kuller L, Lopez AM, Manson J, Margolis KL, Muti PC, et al. Obesity, body size, and risk of postmenopausal breast cancer: the Women's Health Initiative (United States). Cancer Causes Control. 2002:13(8):741-51.

9. Bandera EV, Chandran U, Hong CC, Troester MA, Bethea TN, Adams-Campbell LL, Haiman CA, Park SY, Olshan AF, Ambrosone CB.et al. Obesity, body fat distribution, and risk of breast cancer subtypes in African American women participating in the AMBER Consortium. Breast Cancer Res Treat. 2015;150(3):655-66.

10. Eichholzer M, Huang DJ, Modlasiak A, Schmid SM, Schotzau A, Rohrmann S, Guth U. Impact of body mass index on prognostically relevant breast cancer tumor characteristics. Breast Care (Basel). 2013;8(3):192-8.

11. Kwan ML, Kroenke CH, Sweeney C, Bernard PS, Weltzien EK, Castillo A Factor RE, Maxfield KS, Stijleman IJ, Kushi LH, et al. Association of high obesity with PAM50 breast cancer intrinsic subtypes and gene expression. BMC Cancer. 2015;15:278.

12. Kwan ML, Kushi LH, Weltzien E, Maring B, Kutner SE, Fulton RS, Lee MM, Ambrosone CB, Caan BJ. Epidemiology of breast cancer subtypes in two prospective cohort studies of breast cancer survivors. Breast Cancer Res. 2009;11(3):R31.

13. Phipps Al, Malone KE, Porter PL, Daling JR, Li Cl. Body size and risk of luminal, HER2-overexpressing, and triple-negative breast cancer in postmenopausal women. Cancer Epidemiol Biomarker Prev. 2008;17(8):2078-86.

14. Pierobon M, Frankenfeld CL. Obesity as a risk factor for triple-negative breast cancers: a systematic review and meta-analysis. Breast Cancer Res Treat. 2013;137(1):307-14

15. Yanai A, Miyagawa Y, Murase K, Imamura M, Yagi T, Ichii S, Takatsuka Y, Ito T, Hirota S, Sasa M, et al. Influence of body mass index on clinicopathological factors including estrogen receptor, progesterone receptor, and Ki67 expression levels in breast cancers. Int J Clin Oncol. 2014; 19(3):467-72.

16. Haakinson DJ, Leeds SG, Dueck AC, Gray RJ, Wasif N, Stucky CC, Northfelt DW, Apsey HA, Pockaj B. The impact of obesity on breast cancer: a retrospective review. Ann Surg Oncol. 2012;19(9):3012-8.

17. Majed B, Moreau T, Senouci K, Salmon RJ, Fourquet A, Asselain B. Is obesity an independent prognosis factor in woman breast cancer? Breast Cancer Res Treat. 2008:111(2):329-42.

18. Kann S, Schmid SM, Eichholzer M, Huang DJ, Amann E, Guth U. The impact of overweight and obesity on breast cancer: data from Switzerland, so far a country little affected by the current global obesity epidemic. Gland Surgery. 2014;3(3):181-97.

19. Moorman PG, Jones BA, Millikan RC, Hall IJ, Newman B. Race, anthropometric factors, and stage at diagnosis of breast cancer. Am J Epidemiol. 2001;153(3):284-91

20. Niraula S, Ocana A, Ennis M, Goodwin PJ. Body size and breast cancer prognosis in relation to hormone receptor and menopausal status: a meta-analysis. Breast Cancer Res Treat. 2012;134(2):769-81.

21. Protani M, Coory M, Martin JH. Effect of obesity on survival of women with breast cancer: systematic review and meta-analysis. Breast Cancer Res Treat. 2010:123(3):627-35.

22. Jain R, Strickler HD, Fine E, Sparano JA. Clinical studies examining the impact of obesity on breast cancer risk and prognosis. J Mammary Gland Biol Neoplasia. 2013;18(3-4):257-66

23. Ford NA, Devlin KL, Lashinger LM, Hursting SD. Deconvoluting the obesity and breast cancer link: secretome, soil and seed interactions. J Mammary Gland Biol Neoplasia. 2013;18(3-4):267-75.

24. American Joint Committee on C. AJCC Cancer Staging Manual, vol. 7th. New York: Springer; 2010

25. Bloom HJ, Richardson WW. Histological grading and prognosis in breast cancer; a study of 1409 cases of which 359 have been followed for 15 years. Br J Cancer. 1957;11(3):359-77. 
26. Elston CW, Ellis IO. Pathological prognostic factors in breast cancer. I. The value of histological grade in breast cancer: experience from a large study with long-term follow-up. Histopathology. 1991;19(5):403-10.

27. Deyarmin B, Kane JL, Valente AL, van Laar R, Gallagher C, Shriver CD, Ellsworth RE. Effect of ASCO/CAP guidelines for determining ER status on molecular subtype. Ann Surg Oncol. 2013;20(1):87-93.

28. Field LA, Deyarmin B, Shriver CD, Ellsworth DL, Ellsworth RE. Laser microdissection for gene expression profiling. Methods MolBiol. 2011;755(17):45.

29. Ng M, Fleming T, Robinson M, Thomson B, Graetz N, Margono C, Mullany EC, Biryukov S, Abbafati C, Abera SF, et al. Global, regional, and national prevalence of overweight and obesity in children and adults during 19802013: a systematic analysis for the Global Burden of Disease Study 2013. Lancet. 2014;384(9945):766-81.

30. Fuentes-Mattei E, Velazquez-Torres G, Phan L, Zhang F, Chou PC, Shin JH, Choi HH, Chen JS, Zhao R, Chen J, et al. Effects of obesity on transcriptomic changes and cancer hallmarks in estrogen receptor-positive breast cancer. J Natl Cancer Inst. 2014; 106(7): dju158.

31. Creighton CJ, Sada YH, Zhang Y, Tsimelzon A, Wong H, Dave B, Landis MD, Bear HD, Rodriguez A, Chang JC. A gene transcription signature of obesity in breast cancer. Breast Cancer Res Treat. 2012;132(3):993-1000.

32. Allard JE, Chandramouli GV, Stagliano K, Hood BL, Litzi T, Shoji Y, Boyd J, Berchuck A, Conrads TP, Maxwell GL, et al. Analysis of PSPHL as a candidate gene influencing the racial disparity in endometrial cancer. FrontOncol. 2012;2:65.

33. Jovov B, Araujo-Perez F, Sigel CS, Stratford JK, McCoy AN, Yeh JJ, Keku T. Differential gene expression between African American and European American colorectal cancer patients. Plos ONE. 2012;7(1):e30168.

34. Martin DN, Boersma BJ, Yi M, Reimers M, Howe TM, Yfantis HG, Tsai YC, Williams EH, Lee DH, Stephens RM, et al. Differences in the tumor microenvironment between African-American and European-American breast cancer patients. Plos ONE. 2009;4(2):e4531.

35. Wallace TA, Prueitt RL, Yi M, Howe TM, Gillespie JW, Yfantis HG, Stephens RM, Caporaso NE, Loffredo CA, Ambs S. Tumor immunobiological differences in prostate cancer between African-American and EuropeanAmerican men. Cancer Res. 2008;68(3):927-36.

36. Miao H, Chen L, Riordan SM, Li W, Juarez S, Crabb AM, Lukas TJ, Du P, Lin SM, Wise A, et al. Gene expression and functional studies of the optic nerve head astrocyte transcriptome from normal African Americans and Caucasian Americans donors. Plos ONE. 2008;3(8):e2847.

37. Field LA, Love B, Deyarmin B, Hooke JA, Shriver CD, Ellsworth RE. Identification of differentially expressed genes in breast tumors from African American compared with Caucasian women. Cancer. 2012;118(5):1334-44.

38. Rummel S, Penatzer CE, Shriver CD, Ellsworth RE. PSPHL and breast cancer in African American women: causative gene or population stratification? BMC Genet. 2014;15(1):38.

39. Wei P, Milbauer LC, Enenstein J, Nguyen J, Pan W, Hebbel RP. Differentia endothelial cell gene expression by African Americans versus Caucasian Americans: a possible contribution to health disparity in vascular disease and cancer. BMC Med. 2011;9:2.

40. Sundaram S, Johnson AR, Makowski L. Obesity, metabolism and the microenvironment: links to cancer. JCarcinog. 2013;12:9.

41. Sturtz LA, Deyarmin B, van Laar R, Yarina W, Shriver CD, Ellsworth RE. Gene expression differences in adipose tissue associated with breast tumorigenesis. Adipocyte. 2014;3(2):107-14.

42. Strong AL, Ohlstein JF, Biagas BA, Rhodes LV, Pei DT, Tucker HA, Llamas C, Bowles AC, Dutreil MF, Zhang S, et al. Leptin produced by obese adipose stromal/stem cells enhances proliferation and metastasis of estrogen receptor positive breast cancers. Breast Cancer Res. 2015;17:112.

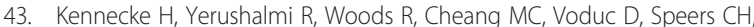
Nielsen TO, Gelmon K. Metastatic behavior of breast cancer subtypes. JClinOncol. 2010;28(20):3271-7.

\section{Submit your next manuscript to BioMed Central and we will help you at every step:}

- We accept pre-submission inquiries

- Our selector tool helps you to find the most relevant journal

- We provide round the clock customer support

- Convenient online submission

- Thorough peer review

- Inclusion in PubMed and all major indexing services

- Maximum visibility for your research

Submit your manuscript at www.biomedcentral.com/submit
() BioMed Central 